\title{
Phosphorylation of Nonhistone Proteins During Premature Chromosome Condensation in a Temperature-Sensitive Mutant, tsBN2
}

\author{
Katsumi Yamashita ${ }^{1}$, Frances M. Davis ${ }^{2}$, Potu N. Rao ${ }^{2}$, \\ Mutsuo Sekiguchi $^{1}$ and Takeharu Nishimoto ${ }^{1}$ \\ ${ }^{1}$ Department of Biology, Faculty of Science, Kyushu University 33, Fukuoka \\ 812, Japan and 2 Department of Chemotherapy Research, The University of \\ Texas M.D. Anderson Hospital and Tumor Institute, Houston, Texas 77030, \\ U.S.A.
}

\begin{abstract}
In tsBN2 cells, a temperature-sensitive (ts) mutant of the BHK21 cell line, with a ts-defect in its regulatory system for chromosome condensation, antigens that react with mitotic specific mouse monoclonal antibody MPM-2 were produced when premature chromosome condensation (PCC) was induced by a temperature shift. The polypeptides of antigens recognized by MPM-2 in tsBN2 cells with PCC were identical to those of antigens in mitotic cells. These antigens appeared concomitantly with chromosome condensation, which suggests that these mitotic-specific antigens may be related to chromosome condensation. As the production of mitotic-specific antigens was inhibited by W-7, a specific and potent antagonist of calmodulin, calmodulin may function in the mitotic phosphorylation of nonhistone protein.
\end{abstract}

Mitotic cells contain certain factors that induce premature chromosome condensation (PCC) in interphase cells following fusion between mitotic and interphase cells (13). Extracts of mitotic cells injected into the immature oocyte of Xenopus laevis induce germinal vesicle breakdown and chromosome condensation $(1,15,20)$.

tsBN2, a temperature-sensitive mutant of baby hamster kidney cells (BHK21), shows PCC at the nonpermissive temperature of $40.5^{\circ} \mathrm{C}(16-18)$. Similar to mitotic cells, tsBN2 cells showing PCC can induce PCC in an interphase cell, upon cell-fusion (10). A $35-\mathrm{kDa}$ phosphoprotein found specifically in mitotic cells also has been detected in tsBN2 cells showing PCC (24). In addition, Ajiro et al. (2) have found that histones $\mathrm{H} 1$ and $\mathrm{H} 3$ are phosphorylated in tsBN2 cells showing PCC, in same manner as in mitotic cells $(3,5,8,9)$.

The monoclonal antibodies, MPM-1 and MPM-2, raised against extracts of mitotic HeLa cells by Davis et al. (7), react specifically with mitotic cells and recognize a family of nonhistone-phosphopolypeptides. No causal relationship between the appearance of mitotic-specific antigens and chromosome condensation, however, has

Abbreviations used: PCC, premature chromosome condensation; BHK, baby hamster kidney cells; DME, Dulbecco's modified Eagle's medium; HU, hydroxyurea; TD, Tris-buffered saline without $\mathrm{Ca}^{2+}$ and $\mathrm{Mg}^{2+}$; PBS, phosphate-buffered saline; W-7, N-(6-aminohexyl)-5-chloro-1naphthalenesulfonamide- $\mathrm{HCl}$; W-5, N-(6-aminohexyl)-1-naphthalenesulfonamide- $\mathrm{HCl}$. 
been established.

The study presented here was done to determine whether the antigens recognizable with mitotic-specific, monoclonal antibody appear in tsBN2 cells showing PCC, and to investigate the causal relation between the appearance of mitotic-specific antigens and the induction of chromosome condensation. Because the phosphorylation of histones $\mathrm{H} 1$ and $\mathrm{H} 2$ is reported to be inhibited by W-7, a specific inhibitor of calmodulin $(11,16)$, the effect of this drug on the appearance of mitotic-specific antigens also was investigated. The monoclonal antibody MPM-2 was used for these studies.

\section{MATERIALS AND METHODS}

Chemicals and antibody. W-7 (N-(6-aminohexyl)-5-chloro-1-naphthalenesulfonamide$\mathrm{HCl})$ and $\mathrm{W}-5$ (N-(6-aminohexyl)-1-naphthalenesulfonamide- $\mathrm{HCl})$ were purchased from Rikaken Co. Ltd. The monoclonal antibody, MPM-2 which reacts with phosphoproteins of HeLa mitotic cells was obtained from ascitis fluid as described elsewhere (7).

Cell and medium. Wild type BHK21 and its temperature-sensitive derivative, tsBN2 cells were cultured at $33.5^{\circ} \mathrm{C}$ in a humidified atmosphere containing $10 \% \mathrm{CO}_{2}$ in Dulbecco's modified Eagle's medium (DME) supplemented with $10 \%$ calf serum. As the nonpermissive temperature, $40.5^{\circ} \mathrm{C}$ was used.

Cell synchrony. BHK21 and tsBN2 were synchronized at the beginning of the S phase by the use of isoleucine deprivation and hydroxyurea (HU) as described elsewhere (19). To obtain cells in the M phase, BHK21 and tsBN2 cells synchronized at the beginning of the $\mathrm{S}$ phase were washed once with Tris-buffered saline without $\mathrm{Ca}^{2+}$ and $\mathrm{Mg}^{2+}$ (TD) then fed DME containing $10 \%$ calf serum. After incubation at $33.5^{\circ} \mathrm{C}$ for $6 \mathrm{~h}, 1 \mu \mathrm{g} / \mathrm{ml}$ of colcemid was added then incubation was continued for another $8 \mathrm{~h}$. Mitotic cells were collected by pipetting. The typical mitotic index of BHK21 was $78.5 \%$.

Indirect immunofluorescence microscopy. Cells plated on cover glass or deposited on slides by cytocentrifugation were rinsed once with phosphate-buffered saline (PBS) then fixed in $10 \%$ formaldehyde in PBS for 5 min at room temperature. After washing these cells twice with PBS, they were post-fixed in methanol for $5 \mathrm{~min}$ at $30^{\circ} \mathrm{C}$ with gentle shaking then washed 3 times with PBS and air-dried. The dried cells were overlaid with $50 \mu 1$ of the primary antibody (MPM-2, 1:2000) then incubated in a humidified atmosphere for $30 \mathrm{~min}$ at $37^{\circ} \mathrm{C}$. After washing them 3 times with PBS, the cells were treated with fluorescein isothiocyanate (FITC)-conjugated rabbit anti-mouse IgG, heavy and light chains (Miles) $(1: 50)$ and mounted in $80 \%$ glycerol. When indicated, their DNA was stained with propidium iodide $(0.3 \mu \mathrm{g} / \mathrm{ml})$ for $10 \mathrm{~min}$.

Sodium dodecyl sulfate (SDS)-polyacrylamide gel electrophoresis and immunoblotting. The collected cells were washed once with ice-cold buffer containing $20 \mathrm{mM}$ Tris- $\mathrm{HCl}$ (pH 7.5), $100 \mathrm{mM} \mathrm{NaCl}$ and $50 \mathrm{mM} \mathrm{NaHSO}_{3}$ and cells were suspended in the sample buffer containing $62.5 \mathrm{mM}$ Tris- $\mathrm{HCl}$ (pH 6.8), $10 \mathrm{mM} 2$-mercaptoethanol, 3\% (w/v) SDS and $20 \%$ glycerol. The cells were sonicated briefly then boiled for $5 \mathrm{~min}$, after which they were electrophoresed on $7.5-15 \%$ linear gradient polyacrylamide gels (14). Blotting of proteins from the polyacrylamide gels onto nitrocellulose filters was done electrophoretically at $20 \mathrm{~V}$ for $30 \mathrm{~min}$ then at $40 \mathrm{~V}$ for $12 \mathrm{~h}$, under cooling $(6,22)$.

Immunoreactive proteins were detected with a Vectastain ABC kit (Vector Laboratory, Inc.): Nitrocellulose filters were immersed in a solution of $20 \mathrm{mM}$ Tris- $\mathrm{HCl}(\mathrm{pH} \mathrm{7.5)}$ and $0.9 \% \mathrm{NaCl}$ (TBS) containing $3 \%$ gelatin (Bio-Rad Laboratories) then shaken at $37^{\circ} \mathrm{C}$ for 
at least $1 \mathrm{~h}$. Both the primary and secondary antibodies reacted in TBS containing $1 \%$ gelatin. The diluted primary antibody $(1: 10,000)$ was incubated with nitrocellulose filters for $2 \mathrm{~h}$ at room temperature. All procedures subsequent to blockage of the nitrocellulose filters were done according to the biotin-avidin-peroxidase method given in the supplier's manual, except that TBS or TBS containing $0.1 \%$ Tween 20 , instead of PBS or PBS containing $0.1 \%$ Tween 20 was used.

Immunoprecipitation of ${ }^{32}$ P-labeled proteins. BHK21 cells and tsBN2 cells were plated at the concentration of $5 \times 10^{5}$ cells $/ 100-\mathrm{mm}$ dish then synchronized at the beginning of $\mathrm{S}$ phase by the use of isoleucine deprivation and hydroxyurea (24). After 3 washes with phosphate-free Tris-buffered saline, the cultures were fed phosphate-free DME containing [ $\left.{ }^{32} \mathrm{P}\right]$ orthophosphate $(125 \mathrm{Ci} / \mathrm{ml})$. BHK21 cells and half of the tsBN2 cells were shifted up to $40.5^{\circ} \mathrm{C}$ and incubated for $2.5 \mathrm{~h}$. After this labeling, the cells were collected with a Teflonscraper then suspended in $7 \mathrm{ml}$ of ice-cold buffer containing $25 \mathrm{mM}$ Tris- $\mathrm{HCl}$ (pH 7.5), $100 \mathrm{mM} \mathrm{NaCl}$ and $50 \mathrm{mM} \mathrm{NaHCO}_{3}$. They then were washed twice with the same ice-cold buffer and suspended in $250 \mu \mathrm{l}$ of immunoprecipitation buffer containing $25 \mathrm{mM}$ Tris- $\mathrm{HCl}$ (pH 7.5), $100 \mathrm{mM} \mathrm{NaCl}, 25 \mathrm{mM} \mathrm{NaHCO}, 1 \mathrm{mM} \mathrm{MgCl} 2,1 \mathrm{mM} \mathrm{CaCl}, 1 \% \mathrm{NP} 40,0.5 \%$ deoxycolate and $1 \mathrm{mM}$ phenylmethylsulfonylfluoide.

The suspended cells were whirled vigorously in a Vortex mixer for $10 \mathrm{~s}$ then disrupted by 10 passages through a 26 gauge syringe. The homogenates were centrifuged at $40,000 \times \mathrm{g}$ for $30 \mathrm{~min}$ at $4^{\circ} \mathrm{C}$. $100 \mu 1$ of IgG.Sorb (Enzyme Center, Inc., Ma. U.S.A.) that had been adsorbed with rabbit antimouse IgG (Miles.) was added to the supernatant. This mixtures was rotated gently for $2 \mathrm{~h}$ at $4^{\circ} \mathrm{C}$ then centrifuged at $15,000 \times \mathrm{g}$ for $5 \mathrm{~min}$ at $4^{\circ} \mathrm{C}$, then $25 \mu \mathrm{l}$ of MPM-2 (1:4000) was added to the supernatant. This mixtures was rotated gently for $12 \mathrm{~h}$ at $4^{\circ} \mathrm{C}$, then combined with $100 \mu \mathrm{l}$ of IgG.Sorb that had been adsorbed with rabbit antimouse IgG after which it was rotated for $3 \mathrm{~h}$ at $4^{\circ} \mathrm{C}$ followed by centrifugation at $11,000 \times \mathrm{g}$ for $1 \mathrm{~min}$.

The precipitate was suspended in $1 \mathrm{ml}$ of immunoprecipitation buffer by whirling it vigorously in a vortex apparatus, then it was washed 6 times with the immunoprecipitation buffer and suspended in $100 \mu \mathrm{l}$ of SDS-sample buffer. After boiling it for $5 \mathrm{~min}$, the mixture was centrifuged at $15,000 \times \mathrm{g}$ for $5 \mathrm{~min}$. The supernatant $(25 \mu \mathrm{l})$ was electrophoresed on $7.5-15 \%$ linear gradient polyacrylamide gels, as described elsewhere (14). Following electrophoresis, the gels were fixed and stained with $0.1 \%(\mathrm{w} / \mathrm{v})$ Coomassie brilliant blue in $50 \%$ trichloroacetic acid, then they were destained in $10 \%$ ethanol and $5 \%$ acetic acid, after which they were dried and exposed to X-ray film for one day at $-70^{\circ} \mathrm{C}$.

\section{RESULTS}

Recognition of PCC cells by MPM-2 antibody. MPM-2 that recognizes mitotic cells from a variety of animal species (7) also reacts with mitotic cells of both the wild type BHK21 and tsBN2 cells (Fig. 1). We therefore examined the appearance of mitosis-specific antigens in tsBN2 cells showing PCC.

Wild type BHK21 and tsBN2 cells grown in $60-\mathrm{mm}$ plastic dishes were synchronized at the beginning of $\mathrm{S}$ phase with $\mathrm{HU}$, as described in Materials and Methods. Some of the culture dishes were incubated at $40.5^{\circ} \mathrm{C}$ in the presence of $\mathrm{HU}$, others being incubated at the permissive temperature of $33.5^{\circ} \mathrm{C}$ in the presence of $\mathrm{HU}$. After incubation for $3 \mathrm{~h}$, cells were fixed and examined by indirect immunofluorescence. At that time, chromosomal DNA was stained with propidium iodide.

At $40.5^{\circ} \mathrm{C}$, tsBN2 cells showed S-phase-type PCC (Fig. 2, B). Cells showing PCC 

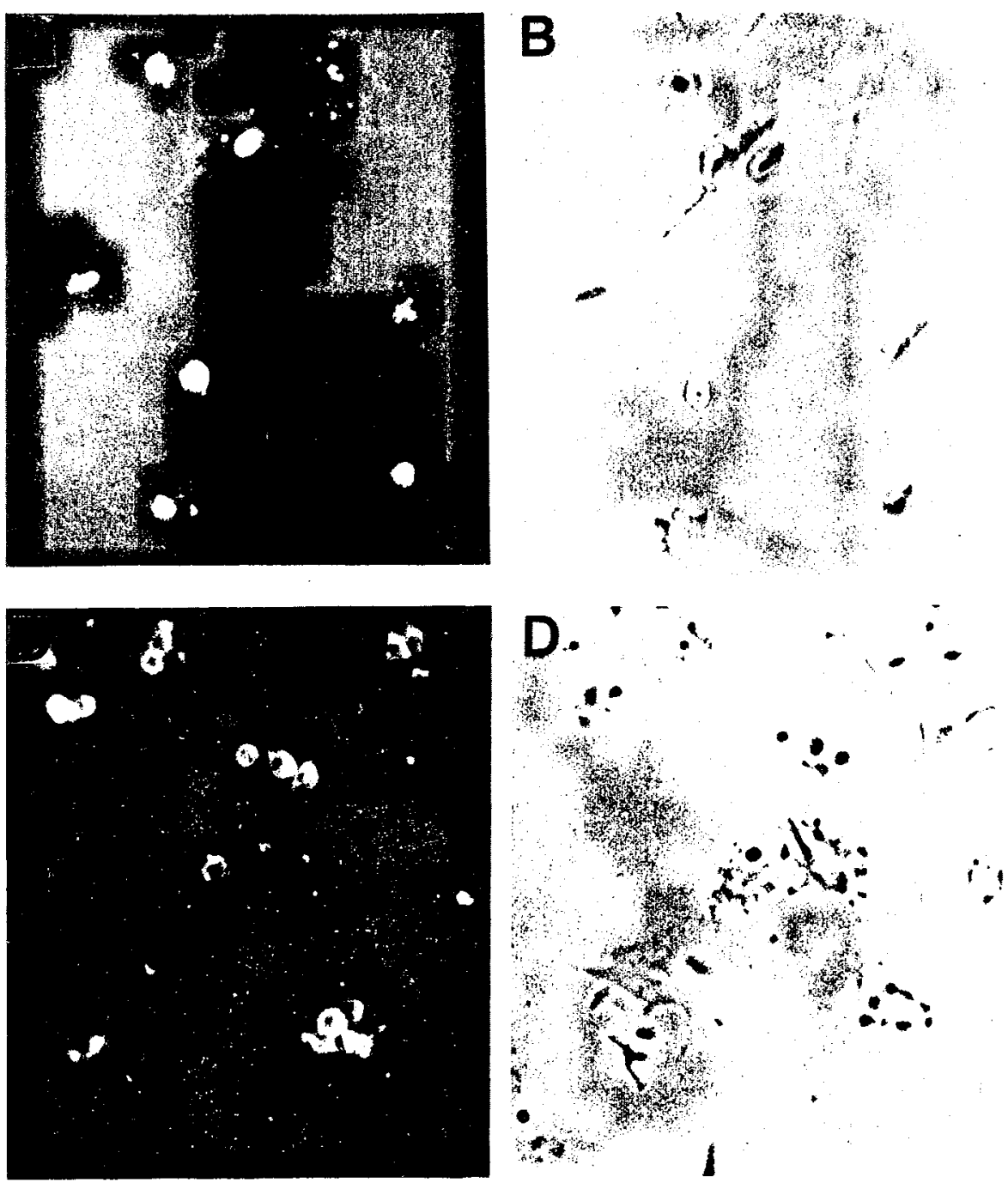

Fig. 1. Recognition of mitotic BHK21 and tsBN2 cells by MPM-2 antibody. BHK21 (A and B) or tsBN2 (C and D) cells seeded on cover glasses were synchronized at the beginning of the $S$ phase then at $\mathrm{M}$ phase with $1 \mu \mathrm{g} / \mathrm{ml}$ of colcemid. Cells on the cover glasses were fixed in methanol and stained using MPM-2 antibodies and FITC-conjugated rabbit antimouse IgG (Miles, Elkhart, Inc., USA). Panels A, C: fluorescence due to antibody reactivity. Panels B, D: phase contrast microscopy of the same cells. $\times 200$.

Fig. 2. MPM-2 reactivity of tsBN2 cells showing $\mathrm{PCC}$ at the non-permissive temperature. Synchronized cultures of tsBN2 cells at the beginning of $\mathrm{S}$ phase were incubated at $40.5^{\circ} \mathrm{C}$ for $3 \mathrm{~h}$ in the presence of $\mathrm{HU}$ then deposited on slides by cytocentrifugation and fixed in methanol. Cells were stained using MPM-2 antibodies and FITC-conjugated rabbit antimouse IgG (Miles, Elkhart, In., USA). DNA in the nuclei, chromosomes and PCC was stained by adding $0.3 \mu \mathrm{g} / \mathrm{ml}$ propidium iodide to the last PBS wash before mounting. Panels A, B : red fluorescence due to propidium iodide; panels C, D: green fluorescence due to antibody reactivity of the same cells (A correspond to C, and B correspond to D). The bars represent $20 \mu \mathrm{m}$. 


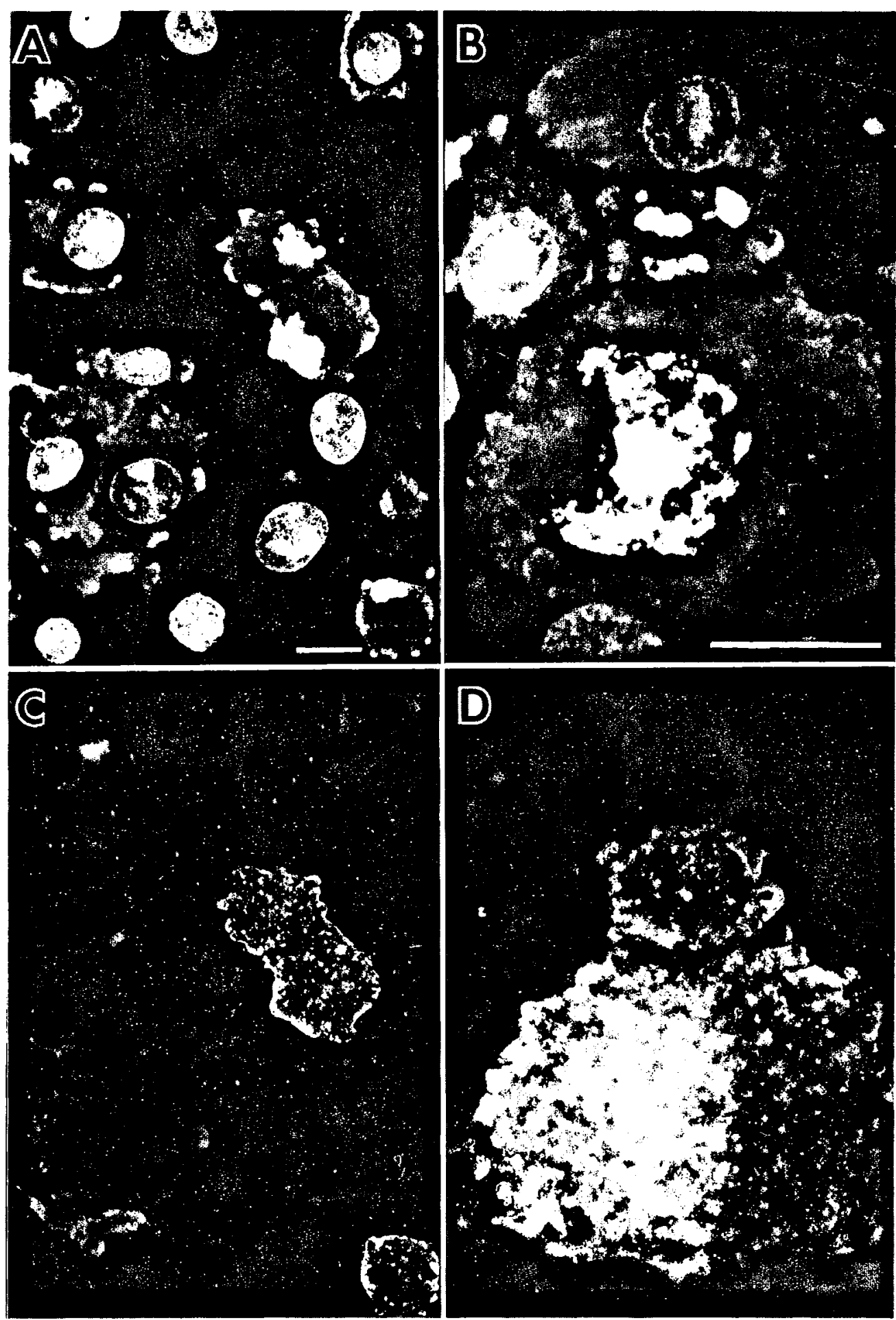


were stained by MPM-2 antibody, but cells with normal nuclei were not (Fig. 2). No specific staining with FITC was found in cultures of tsBN2 cells incubated at $33.5^{\circ} \mathrm{C}$ or in cultures of wild type BHK21 cells incubated at $40.5^{\circ} \mathrm{C}$ (data not shown). The frequency of cells showing PCC in the tsBN2 cultures incubated at $40.5^{\circ} \mathrm{C}$ was the same as that of tsBN2 cells with mitosis-specific antigens (Fig. 2). Therefore, the antibody MPM-2, recognizes not only mitotic cells, but tsBN2 cells showing PCC induced by the temperature shift, as well.

Analysis of antigens by immunoblotting in $t S B N 2$ cell showing PCC. The antigens recognized by MPM-2 antibody in tsBN2 cells showing PCC were compared with those in mitotic cells. Cultures of wild type BHK21 and tsBN2 cells synchronized at the beginning of $\mathrm{S}$ phase were incubated at $40.5^{\circ} \mathrm{C}$ (BHK21 and tsBN2) and $33.5^{\circ} \mathrm{C}$ (tsBN2) for $3 \mathrm{~h}$ in the presence of HU. At the same time, BHK21 and tsBN2 cells were synchronized in mitosis with colcemid, as described in MATERIALS and METHODS. The cellular proteins were separated on gradient SDS polyacrylamide gels by electrophoresis (14), then transferred electrophoretically to nitrocellulose filters (22) and stained by an immunoperoxidase method (6).

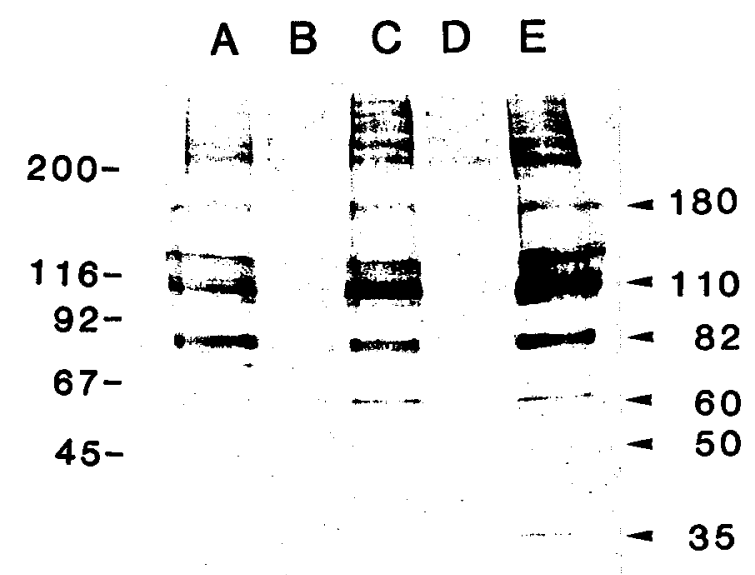

$30-$

20-

Fig. 3. Detection of antigens by immunoblotting. Cultures of wild type BHK21 or tsBN2 cells were synchronized at the beginning of $S$ phase then incubated at $40.5^{\circ} \mathrm{C}$ or $33.5^{\circ} \mathrm{C}$ for $3 \mathrm{~h}$ in the presence of HU. After incubation, whole cells were collected and sonicated. The cell lysates were electrophoresed on $7.5-15 \%$ SDS polyacrylamide gel. After electrophoresis, proteins were transferred to a nitrocellulose filter and the antigens detected as described in MATERIAFs and MeTHODS (B, C, D). Cells synchronized at the beginning of $S$ phase were incubated further for resynchronization at $M$ phase, after which they were collected and processed as described above (A, E). The respective PCC indexes of tsBN2 at $33.5^{\circ} \mathrm{C}$ and $40.5^{\circ} \mathrm{C}$ were $1.3 \%$ and $70.0 \%$, and that of wild type BHK21 at $40.5^{\circ} \mathrm{C}$ was less than $0.5 \%$. The respective mitotic indexes of wild type BHK21 and tsBN2 cells were $66 \%$ and $60 \%$. The molecular weights of protein standards are indicated as $\mathrm{Mw} \times 10^{-3}$. Arrowheads point to proteins that appear specifically in PCC and mitotic cells. A: M phase of tsBN2, B: tsBN2 at $33.5^{\circ} \mathrm{C}, \mathrm{C}$ : tsBN2 at $40.5^{\circ} \mathrm{C}, \mathrm{D}$ : wild type BHK21 at $40.5^{\circ} \mathrm{C}$, E: M phase of wild type BHK21. 
Polypeptides in tsBN2 cells that showed PCC (Fig. 3, C) and were recognized by the antibody, MPM-2, were the same as those in mitotic cells (Fig. 3, A, E). No obvious differences in the composition of the proteins recognized by the antibody were detected for samples of tsBN2 cells showing PCC and samples of mitotic cells. There was little reactivity of these antigens detectable in the $S$ phase cells of tsBN2 cells incubated at $33.5^{\circ} \mathrm{C}$ (Fig. 3, B) or in those of BHK21 cells incubated at $40.5^{\circ} \mathrm{C}$ (Fig. 3, D). Six different polypeptides with molecular weights of 35, 50, 60, 82, 110 and $180 \mathrm{kDa}$ were recognized by MPM-2 in the extracts from mitotic cells, as well as in the extracts from tsBN2 cells showing PCC.

Because antigens recognized by MPM-2 antibody are reported to be phosphorylated (7), we examined whether antigens in tsBN2 cells showing PCC also are. Cultures of tsBN2 and BHK21 cells were synchronized at the beginning of the $S$ phase. After washing the cells thoroughly with phosphate-free Tris-buffered saline, the cultures were fed phosphate-free DME containing [ $\left.{ }^{32} \mathrm{P}\right]$ orthophosphate $(125 \mathrm{Ci} / \mathrm{ml})$. Half the cultures of tsBN2 cells were shifted up to $40.5^{\circ} \mathrm{C}$ and incubated for $2.5 \mathrm{~h}$. As the control, cultures of $\mathrm{BHK} 21$ cells were labeled at $40.5^{\circ} \mathrm{C}$. After this labeling, the cells were collected and disrupted as described in MATERIALS and MeTHODS, Antigens in the cell extract were immunoprecipitated and analyzed by linear gradient gel electrophoresis and by autoradiography, as described in MATERIALS and METHODS.

Immunoprecipitates derived from the cell extracts of tsBN2 cells incubated at $40.5^{\circ} \mathrm{C}$, contained ${ }^{32} \mathrm{P}$-labeled protein (Fig. 4), but not so the precipitates derived from cell extracts of tsBN2 cells incubated at $33.5^{\circ} \mathrm{C}$ and from cell extract of $\mathrm{BHK} 21$ cells incubated at $40.5^{\circ} \mathrm{C}$. Polypeptides with molecular weights of $35,60,82$ and $110 \mathrm{kDa}$ were detected in the precipitates of the cell extracts derived from tsBN2 cells incubated at $40.5^{\circ} \mathrm{C}$. This is evidence that the MPM-2-reacting antigens in tsBN2 cells showing PCC are phosphorylated, as are the antigens in mitotic cells.

Relation of the induction of PCC to the accumulation of antigenes. The appearance

Fig. 4. Phosphorylation of MPM-2-reacting antigens produced in tsBN2 cells showing PCC. Cultures of BHK21 or tsBN2 cells synchronized at the beginning of $\mathrm{S}$ phase by the use of isoleucine deprivation and HU (19) were washed with phosphate-free Trisbuffered saline and fed $2 \mathrm{ml}$ of phosphate-free DME containing [ $\left.{ }^{32} \mathrm{P}\right]$ orthophosphate $(125 \mathrm{Ci} / \mathrm{ml})$. The $\mathrm{BHK} 21$-cultures and half of the tsBN2-cultures were then shifted to $40.5^{\circ} \mathrm{C}$ and incubated for $2.5 \mathrm{~h}$. The labeled cells were collected with a Teflon scraper and processed as described in Materials and Methods. Antigens reacting with MPM-2 were precipitated by IgG.Sorb (The Enzyme Center, Inc., MA. U.S.A.) that had been adsorbed with rabbit antimouse IgG, then they were analyzed by polyacrylamide gel electrophoresis as described in Material and Methods. Lane a: extracts of $\mathrm{BHK} 21$ cells incubated at $40.5^{\circ} \mathrm{C}$. Lane b: extracts of tsBN2 cells incubated at $40.5^{\circ} \mathrm{C}$. Lane c: extracts of tsBN2 cells incubated at $33.5^{\circ} \mathrm{C}$.

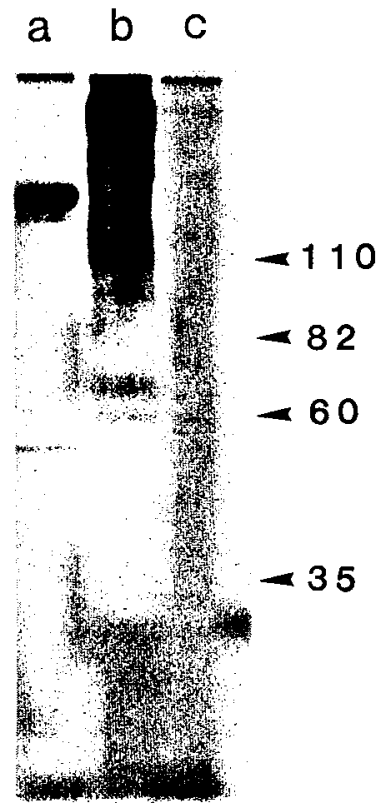




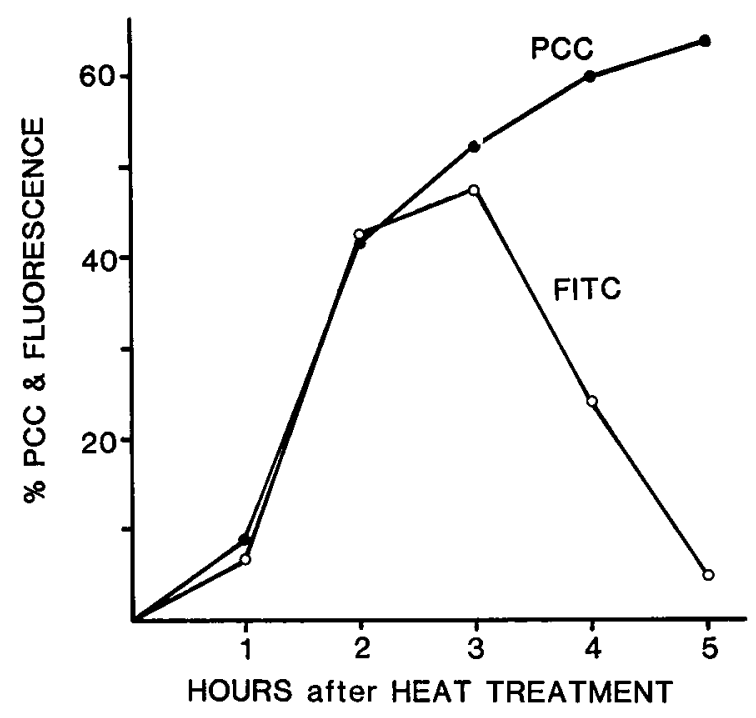

Fig. 5. Induction of antigens detected by indirect immunofluorescence. Cultures of tsBN2 cells synchronized at the beginning of $S$ phase were incubated at $40.5^{\circ} \mathrm{C}$. Every hour after the temperature shift, samples were collected and stained by indirect immunofluorescence or used to count the frequency of PCC. The ordinate shows the frequency of cells stained with fluorescence $\left(-\mathrm{O}^{-}\right)$or cells showing PCC (-)

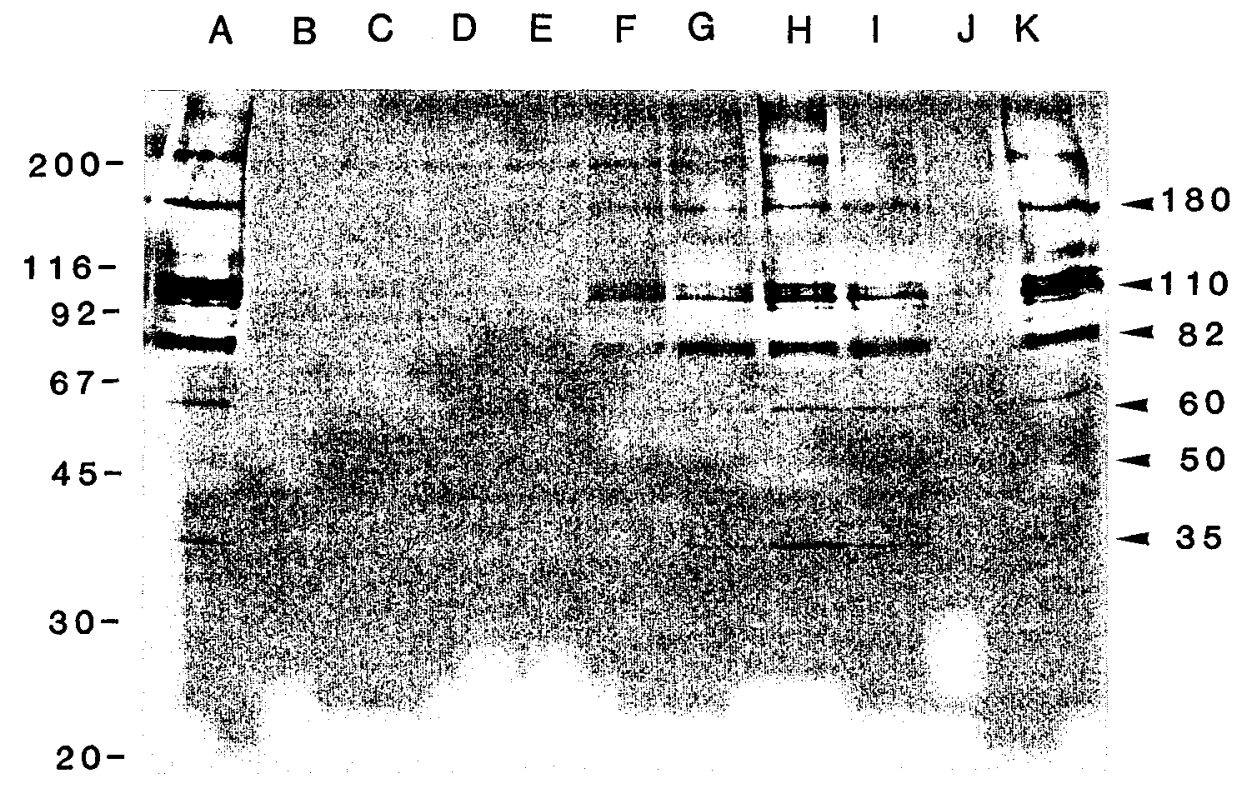

Fig. 6. Induction of antigens detected by immunoblotting. Cultures of tsBN2 cells synchronized at the beginning of $S$ phase were incubated at $40.5^{\circ} \mathrm{C}$. At the times 0 (B), $30 \mathrm{~min}(\mathrm{C}), 1 \mathrm{~h}$ (D), $1.5 \mathrm{~h}$ (E), $2 \mathrm{~h}(\mathrm{~F}), 2.5 \mathrm{~h}(\mathrm{G}), 3 \mathrm{~h}(\mathrm{H}), 4 \mathrm{~h}(\mathrm{I})$ and $5 \mathrm{~h}(\mathrm{~J})$ following the temperature shift, samples were collected and the antigens present were analyzed as described in the legend to Fig. 2. The molecular weights of the proteins are shown as $\mathrm{Mw} \times 10^{-3}$. A and $\mathrm{K}$ were the respective mitotic samples of ts BN2 cells at $33.5^{\circ} \mathrm{C}$ and of wild type BHK21. PCC indexes of the samples for lanes B through $J$ were $0,0.3,1.4,5,24,40,47,60$ and $55 \%$. 
of PCC cells in cultures of tsBN2 cells at the nonpermissive temperature starts to be observed during the 2 nd $h$ after the temperature shift $(16,18)$. We therefore investigated at what stage antigens specific for mitotic cells are produced during the induction of PCC. tsBN2 cells synchronized at the beginning of the $\mathrm{S}$ phase were shifted to $40.5^{\circ} \mathrm{C}$. Each hour following the temperature shift, cells were scraped from the dish, centrifuged then suspended in TD. Some of these cells were processed to determine the PCC index, the remainder being fixed after cytocentrifugation and processed for indirect immunofluorescence.

The frequencies of both PCC and cells stained with MPM-2 were comparable up to the $3 \mathrm{rd} \mathrm{h}$ (Fig. 5). Both appeared during the $2 \mathrm{nd} \mathrm{h}$ after the temperature shift and increased for another hour. On further incubation, the frequency of cells stained with MPM-2 decreased, whereas the frequency of cells showing PCC continued to increase.

The appearance of antigenic polypeptides also was followed during PCC induction. All the mitosis-specific antigens mentioned previously appeared at the $2 \mathrm{nd} \mathrm{h}$ after the shift to $40.5^{\circ} \mathrm{C}$ (Fig. 6). No specific band was detected before this time. We found in our indirect immunofluorescent study that these mitosis-specific antigens began to decrease during the 4 th $\mathrm{h}$ and were undetectable by the 5 th $\mathrm{h}$ after the temperature shift.

Inhibition of antigen production by the calmodulin antagonist, W-7. In a recent study, Nishimoto et al. (16) found that mitosis-specific phosphorylation of histones $\mathrm{H} 1$ and $\mathrm{H} 3$ is inhibited in the presence of $\mathrm{W}-7$, a specific calmodulin antagonist and that this results in no induction of $\mathrm{PCC}$ in cultures of tsBN2 cells at $40.5^{\circ} \mathrm{C}$. Therefore,

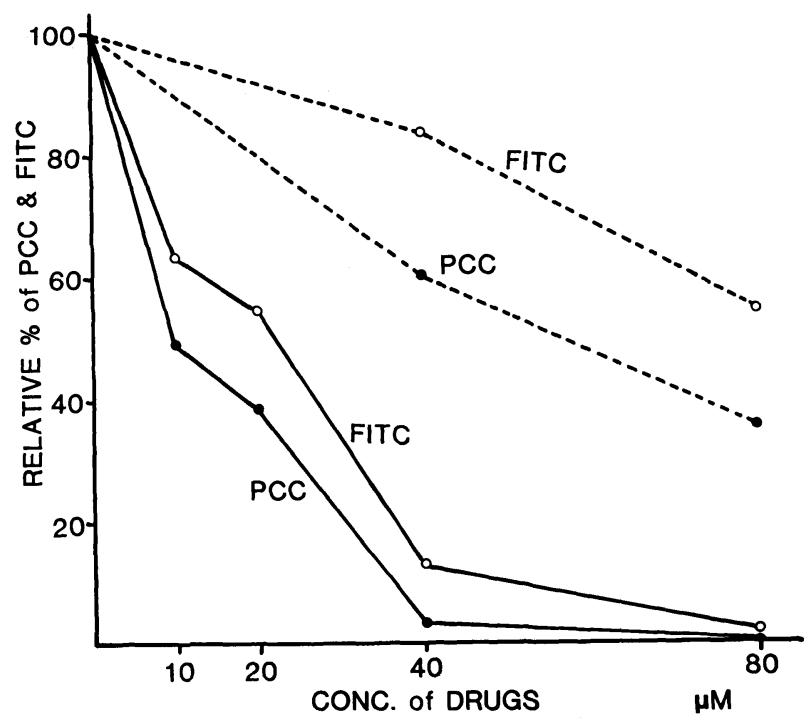

Fig. 7. Inhibition of antigen production and PCC induction by W-7. Cultures of tsBN2 cells synchronized at the beginning of $\mathrm{S}$ phase were incubated at $40.5^{\circ} \mathrm{C}$ for $3 \mathrm{~h}$ in the presence of $\mathrm{W}-7$ (-) or W-5 (---). After incubation, cells were collected and processed for staining with indirect immunofluorescence (FITC) $\left(-\mathrm{O}^{-}\right)$, or used for counting the frequency of PCC (-). The ordinate gives the percent of frequency in the presence of the drugs (W-7 or W-5) relative to that in their absence. The control value for PCC frequency was $57 \%$ and that for the frequency of cells stained with fluorescence $38 \%$. 
we investigated the effect of W-7 on the appearance of mitosis-specific nonhistone phosphoprotein antigens during PCC induction.

tsBN2 cells synchronized at the beginning of $\mathrm{S}$ phase were shifted to $40.5^{\circ} \mathrm{C}$ then incubated for $3 \mathrm{~h}$ in the presence of various concentrations of W-7 or W-5, a chlorinedeficient analog of W-7 that has a less inhibitory effect on calmodulin (11). Cells that had been treated with these drugs were collected, cytocentrifuged then fixed, after which the presence of mitosis-specific antigens in them was checked by indirect immunofluorescence. At the same time, the PCC indexes were determined.

Dose-dependent inhibition of PCC induction and of the appearance of cells having mitosis-specific antigens was found (Fig. 7). Maximum inhibition with W-7 took place at a concentration of $40 \mu \mathrm{M}$. W-5 was much less effective. In the presence of W-7 $(40 \mu \mathrm{M})$, none of the antigens recognized by MPM-2 appeared, as shown by immunoblotting (data not shown).

\section{DISCUSSION}

Ajiro et al. (2) demonstrated that the mitosis-specific phosphorylation of histones $\mathrm{H} 1$ and $\mathrm{H} 3$ is induced in tsBN2 cells showing PCC. Using the monoclonal, mitoticspecific antibody, MPM-2, we found that the mitosis-specific phosphorylation of nonhistone proteins also is induced in tsBN2 cells showing PCC. There was no distinguishable difference between the species of nonhistone phosphoprotein antigens present in tsBN2 cells showing PCC and those in normal mitotic cells. Thus, the mitotic-specific phosphorylations of histone and nonhistone proteins induced in tsBN2 cells showing PCC probably are regulated by the single gene that is responsible for the temperature-sensitive phenotype of tsBN2 cells.

When chromosome condensation became apparant, all the MPM-2-reacting antigens appeared synchronously. At that time, the mitotic-specific phosphorylation of histones $\mathrm{H} 1$ and $\mathrm{H} 3$ also began $(2,16)$. Thus, the appearance of mitotic-specific phosphorylation coincided with the appearance of chromosome condensation. It is impossible to order these events temporally. A limiting factor for the appearance of these mitotic-specific events may be the production of a protein that triggers the cascade of actions toward chromosome condensation.

In Shizosaccharomyces pombe, the product of the cdc2 gene, which has been estimated to have the activity of a protein kinase (12), initiates mitosis (4). Such a protein kinase (12), or the activator of such a kinase would be newly synthesized in animal cells before the condensation of the chromosome because cycloheximide, an inhibitor of protein synthesis, prevents the initiation of normal mitosis (21) and the induction of chromosome condensation in tsBN2 cells at the nonpermissive temperature $(2,18)$. With the W-7-induced inhibition of mitotic-specific phosphorylation of histone (16) and nonhistone proteins, the tsBN2 cells showing PCC decreased. This suggests that there is a causal relation between mitotic-specific phosphorylation and chromosome condensation. Because W-7 is a potent and specific antagonist of calmodulin (11), this ubiquitous protein may act in chromosome condensation. Wasserman and Smith (23) found that germinal vesicle breakdown in immature Xenopus oocytes is induced by calmodulin.

During the 4 th $\mathrm{h}$ after a temperature shift to $40.5^{\circ} \mathrm{C}$, the content of MPM-2reacting antigens decreased. At the same time, the content of calmodulin and the degree of histone phosphorylation decreased (16), which suggests some relation 
between the calmodulin content and the extent of phosphorylation.

Among the mitotic-specific antigens present, a $35-\mathrm{kDa}$ protein was detected. This protein may be the same as the $35-\mathrm{kDa}$ protein which we found previously by twodimensional electrophoretic analysis in tsBN2 cells showing PCC (24). That $35-\mathrm{kDa}$ protein is synthesized specifically in the period from G2 to mitosis in the normal cell cycle and also is phosphorylated. Because that $35-\mathrm{kDa}$ protein binds tightly the condensed chromosomes (24), it is regarded as a possible chromosome condensation factor; but this protein was not detectable before the appearance of PCC.

Acknowledgments. This research was supported in part by Scientific and Cancer Research Grants from the Ministry of Education, Science and Culture of Japan and by a Grant-in-Aid for Cancer Research from the Ministry of Health and Welfare of Japan. K.Y. was given a postdoctoral grant from the Japan Society for the Promotion of Science. We thank M. Ohora, Kyushu Univ. for her comments on our manuscript.

\section{REFERENCES}

1. Adlakha, R.C., C.G. Sahasrabuddhe, D.A. Wright, W.F. Lindsey and P.N. Rao. Localization of mitotic factors on metaphase chromosomes. J. Cell Sci. 54, 193-206, 1982

2. Ajiro, K., T. Nishimoto and T. TAKAhashi. Histone $\mathrm{H} 1$ and $\mathrm{H} 3$ phosphorylation during premature chromosome condensation in a temperature sensitive mutant (tsBN2) of baby hamster kidney cells. J. Biol. Chem. 258, 4534-4538, 1983

3. Balhorn, R., V. Jackson, D. Granner and R. Chalkley. Phosphorylation of the lysine-rich histones throughout the cell cycle. Biochemistry 14, 2504-2511, 1975

4. BeACH, D., B. DurKacz and P. Nurse. Functionally homologous cell cycle control genes in budding and fission yeast. Nature (London) 300, 706-709, 1982

5. Bradbury, E.M., R.J. Inglis and H.R. Matthews. Control of cell division by very lysine rich histone (F1) phosphorylation. Nature (London) 247, 257-261, 1974

6. BuRnetTE, W.N. "Western blotting": electrophoretic transfer of proteins from sodium dodecyl sulfate-polyacrylamide gels to unmodified nitrocellulose and radiographic detection with antibody and radioiodinated protein A. Anal. Biochem. 112, 195-203, 1981

7. Davis, F.M., T.Y. Tsao, S.K. Fowler and P.N. Rao. Monoclonal antibodies to mitotic cells. Proc. Natl. Acad. Sci. U.S.A. 80, 2926-2930, 1983

8. Gurley, L.R., J.A. D'anna, S.S. Barham, L.L. Deaven and R.A. Tobey. Histone phosphorylation and chromatin structure during mitosis in Chinese hamster cells. Eur. J. Biochem. 84, 1-15, 1978

9. Hanks, S.K., L.V. RodRiguez and P.N. RAO. Relationship between histone phosphorylation and premature chromosome condensation. Exp. Cell Res. 148, 293-302, 1983

10. Hayashi, A., S. Yamamoto, T. Nishimoto and T. Takahashi. Chromosome condensing factor(s) induced in tsBN2 cells at a nonpermissive temperature: evidence for transferable material by cell fusion. Cell Struct. Funct. 7, 291-294, 1982

11. Hidaka, H., Y. Sasaki, T. Tanaka, T. Endo, S. Ohno, Y. Fujil and T. Nagata. N-(6aminohexyl)-5-chloro-1-naphthalenesulfonamide, a calmodulin antagonist, inhibits cell proliferation. Proc. Natl. Acad. Sci. U.S.A. 78, 4354-4357, 1981

12. Hindley, J. and G.A. Phear. Sequence of the cell division gene CDC2 from Schizosaccharomyces pombe; patterns of splicing and homology to protein kinases. Gene 31, 129-134, 1984

13. Johnson, R.T. and P.N. RaO. Mammalian cell fusion: induction of premature chromosome condensation in interphase nuclei. Nature (London) 226, 717-722, 1970

14. LAEMMLI, U.K. Cleavage of structural proteins during the assembly of the head of bacteriophage T4. Nature (London) 227, 680-685, 1970

15. Nelkin, B., C. Nichols and B. Vogelstein. Protein factor(s) from mitotic CHO cells induce 
meiotic maturation in Xenopus laevis oocytes. FEBS Lett. 109, 233-238, 1980

16. Nishimoto, T., K. Ajiro, M. Hirata, K. Yamashita and M. Sekiguchi. The induction of chromosome condensation in tsBN2, a temperature-sensitive mutant of BHK21 was inhibited by the calmodulin antagonist, W-7. Exp. Cell Res. 156, 351-358, 1985

17. Nishimoto, T., E. Eilfen and C. Basilico. Premature chromosome condensation in a ts DNA mutant of BHK cells. Cell 15, 475-483, 1978

18. Nishimoto, T., R. Ishida, K. Ajiro, S. Yamamoto and T. TAKahashi. The synthesis of protein(s) for chromosome condensation may be regulated by a post-transcriptional mechanism. J. Cell. Physiol. 109, 299-308, 1981

19. Nishimoto, T., T. TAKahashi and C. Basilico. A temperature-sensitive mutation affecting S-phase progression can lead to accumulation of cells with a $\mathrm{G}_{2}$ DNA content. Somatic Cell Genet. 6, 465-476, 1980

20. Sunkara, P.S., D.A. Wright and P.N. RaO. Mitotic factors from mammalian cells induce germinal vesicle breakdown and chromosome condensation in amphibian oocytes. Proc. Natl. Acad. Sci. U.S.A. 76, 2799-2802, 1979

21. Tobey, R.A., D.F. Petersen, E.C. Anderson and T.T. Puck. Life cycle analysis of mammalian cells. III. The inhibition of division in Chinese hamster cells by puromycin and actinomycin. Biophys. J. 6, 567-581, 1966

22. Towbin, H., T. Staehelin and J. Gordon. Electrophoretic transfer of proteins from polyacrylamide gels to nitrocellulose sheets: procedure and some applications. Proc. Natl. Acad. Sci. U.S.A. 76, 4350-4354, 1979

23. Wasserman, W.J. and L.D. Smith. Calmodulin triggers the resumption of meiosis in amphibian oocytes. J. Cell Biol. 89, 389-394, 1981

24. Yamashita, K., T. Nishimoto and M. Sekiguchi. Analysis of proteins associated with chromosome condensation in baby hamster kidney cells. J. Biol. Chem. 259, 4667-4671, 1984 